\title{
Photoluminescence Properties of Thulium and Cerium Co-Doped Tantalum-Oxide Films Prepared by Radio-Frequency Co-Sputtering
}

\author{
Kenta Miura*, Takumi Osawa, Yuya Yokota, Tetsuhito Suzuki, Osamu Hanaizumi \\ Graduate School of Science and Technology, Gunma University, Kiryu, Japan \\ Email: " ${ }^{\text {mkenta@gunma-u.ac.jp }}$
}

Received 2 March 2015; accepted 25 March 2015; published 26 March 2015

Copyright $(\subseteq 2015$ by authors and Scientific Research Publishing Inc.

This work is licensed under the Creative Commons Attribution International License (CC BY).

http://creativecommons.org/licenses/by/4.0/

(c) (i) Open Access

\section{Abstract}

We prepared thulium and cerium co-doped tantalum-oxide $\left(\mathrm{Ta}_{2} \mathrm{O}_{5}: \mathrm{Tm}, \mathrm{Ce}\right)$ thin films by radiofrequency co-sputtering of $\mathrm{Tm}_{2} \mathrm{O}_{3}$ and $\mathrm{CeO}_{2}$ pellets on a $\mathrm{Ta}_{2} \mathrm{O}_{5}$ disc for the first time, and photoluminescence (PL) properties of the films annealed at $700^{\circ} \mathrm{C}, 800^{\circ} \mathrm{C}, 900^{\circ} \mathrm{C}$, or $1000^{\circ} \mathrm{C}$ for 20 min were evaluated. PL peaks around a wavelength of $800 \mathrm{~nm}$ due to $\mathrm{Tm}^{3+}$ were observed for films annealed at $900^{\circ} \mathrm{C}$ or $1000^{\circ} \mathrm{C}$. The peak intensities of films prepared using one $\mathrm{Tm}_{2} \mathrm{O}_{3}$ pellet and one $\mathrm{CeO}_{2}$ pellet were much stronger than those of films prepared using one $\mathrm{Tm}_{2} \mathrm{O}_{3}$ pellet and two $\mathrm{CeO}_{2}$ pellets or films prepared using two $\mathrm{Tm}_{2} \mathrm{O}_{3}$ pellets and one $\mathrm{CeO}_{2}$ pellet. To obtain the strongest PL intensity from the film, the proper $\mathrm{Tm}$ concentration was estimated to be around $1.0 \mathrm{~mol} \%$, and the proper Ce concentration was estimated to be around $1.3 \mathrm{~mol} \%$. Such $\mathrm{Ta}_{2} \mathrm{O}_{5}: \mathrm{Tm}, \mathrm{Ce}$ co-sputtered thin films can be used as high-refractive-index materials of autocloned photonic crystals that can be applied to novel light-emitting devices, and they will also be used as anti-reflection and downconversion layers for realizing high-efficiency silicon solar cells.

\section{Keywords}

Tantalum Oxide, Thulium, Cerium, Co-Sputtering, Photoluminescence

\section{Introduction}

Tantalum (V) oxide $\left(\mathrm{Ta}_{2} \mathrm{O}_{5}\right)$ is a high-refractive-index material used in passive optical elements such as $\mathrm{Ta}_{2} \mathrm{O}_{5} /$ $\mathrm{SiO}_{2}$ multilayered wavelength filters for dense wavelength-division multiplexing (DWDM). It has also been used as a high-index material of $\mathrm{Ta}_{2} \mathrm{O}_{5} / \mathrm{SiO}_{2}$ multilayered photonic-crystal elements for the visible to near-

\footnotetext{
${ }^{*}$ Corresponding author.
}

How to cite this paper: Miura, K., Osawa, T., Yokota, Y., Suzuki, T. and Hanaizumi, O. (2015) Photoluminescence Properties of Thulium and Cerium Co-Doped Tantalum-Oxide Films Prepared by Radio-Frequency Co-Sputtering. Materials Sciences and Applications, 6, 263-268. http://dx.doi.org/10.4236/msa.2015.64031 
infrared range fabricated using the "autocloning” method based on radio-frequency (RF) bias sputtering [1]-[3].

However, $\mathrm{Ta}_{2} \mathrm{O}_{5}$ has recently attracted much attention as an active optical material since broad red photoluminescence (PL) spectra at wavelengths of 600 to $650 \mathrm{~nm}$ are observed from thermal-oxidized amorphous $\mathrm{Ta}_{2} \mathrm{O}_{5}$ thin films [4]. We demonstrated blue PL from $\mathrm{Ta}_{2} \mathrm{O}_{5}$ thin films deposited by RF magnetron sputtering [5]. Furthermore, many studies on rare-earth-doped $\mathrm{Ta}_{2} \mathrm{O}_{5}$ have been conducted because $\mathrm{Ta}_{2} \mathrm{O}_{5}$ is a potential host material for new phosphors due to its low phonon energy (100 to $450 \mathrm{~cm}^{-1}$ ) compared with that of other oxide materials (e.g., $\mathrm{SiO}_{2}$ ) [6]. We have reported on various rare-earth (Er, Eu, Y, and Ce) doping into $\mathrm{Ta}_{2} \mathrm{O}_{5}$ thin films using simply co-sputtering of rare-earth oxide $\left(\mathrm{Er}_{2} \mathrm{O}_{3}, \mathrm{Eu}_{2} \mathrm{O}_{3}, \mathrm{Y}_{2} \mathrm{O}_{3}\right.$, and $\left.\mathrm{CeO}_{2}\right)$ pellets and a Ta $\mathrm{O}_{5}$ disc [7]-[11]. Such light-emitting $\mathrm{Ta}_{2} \mathrm{O}_{5}$-based sputtered films can be used as high-refractive-index materials of autocloned photonic crystals that can be applied to novel light-emission devices [1], and they will also be used as antireflection [12] and down-conversion [13] [14] layers for realizing high-efficiency silicon solar cells.

Recently, we have also reported on the preparation of thulium-doped $\mathrm{Ta}_{2} \mathrm{O}_{5}\left(\mathrm{Ta}_{2} \mathrm{O}_{5}: \mathrm{Tm}\right)$ thin films using the same co-sputtering method and their PL properties having sharp peaks around a wavelength of $800 \mathrm{~nm}$ due to $\mathrm{Tm}^{3+}$ [15]. In addition, the sensitization of PL from rare-earth ions by $\mathrm{Ce}^{3+}$ is well known [16]. We can obtain $\mathrm{Ce}^{3+}$ ions by sputtering of $\mathrm{CeO}_{2}$ because a small amount of $\mathrm{Ce}^{3+}$ exists at the surface of $\mathrm{CeO}_{2}$ [17]. It is therefore expected that strong PL will be obtained from Tm and Ce co-doped $\mathrm{Ta}_{2} \mathrm{O}_{5}\left(\mathrm{Ta}_{2} \mathrm{O}_{5}: \mathrm{Tm}\right.$, Ce) thin film deposited by co-sputtering of $\mathrm{Tm}_{2} \mathrm{O}_{3}$ and $\mathrm{CeO}_{2}$ pellets on a $\mathrm{Ta}_{2} \mathrm{O}_{5}$ disc. In this study, we prepared $\mathrm{Ta}_{2} \mathrm{O}_{5}$ :Tm, Ce co-sputtered thin films using RF magnetron sputtering for the first time, and the PL and X-ray diffraction (XRD) properties of the films after annealing at $700^{\circ} \mathrm{C}, 800^{\circ} \mathrm{C}, 900^{\circ} \mathrm{C}$, or $1000^{\circ} \mathrm{C}$ were evaluated.

\section{Experimental}

$\mathrm{Ta}_{2} \mathrm{O}_{5}$ :Tm, Ce thin films were deposited using a RF magnetron sputtering system (ULVAC, SH-350-SE). A $\mathrm{Ta}_{2} \mathrm{O}_{5}$ disc (Furuuchi Chemical Corporation, 99.99\% purity, $100 \mathrm{~mm}$ diameter) was used as the sputtering target. We placed one or two $\mathrm{Tm}_{2} \mathrm{O}_{3}$ and $\mathrm{CeO}_{2}$ pellets (Furuuchi Chemical Corporation, 99.9\% purity, 20 mm diameter) on the $\mathrm{Ta}_{2} \mathrm{O}_{5}$ disc. The $\mathrm{Ta}_{2} \mathrm{O}_{5}$ disc and the $\mathrm{Tm}_{2} \mathrm{O}_{3}$ and $\mathrm{CeO}_{2}$ pellets were co-sputtered by supplying RF power to the target. The flow rate of Ar gas introduced into the vacuum chamber was 15 sccm, and the RF power supplied to the target was $300 \mathrm{~W}$. Commercial fused-silica plates (ATOCK Inc., $1 \mathrm{~mm}$ thick) were used as substrates, and they were not heated during sputtering.

In this study, we deposited three samples (A, B, and C) (Table 1). We changed the Tm or Ce concentrations of the $\mathrm{Ta}_{2} \mathrm{O}_{5}$ :Tm, Ce films by changing the numbers of $\mathrm{Tm}_{2} \mathrm{O}_{3}$ or $\mathrm{CeO}_{2}$ pellets placed on the $\mathrm{Ta}_{2} \mathrm{O}_{5}$ disc [8]. We prepared four specimens from one as-deposited sample by cutting it using a diamond-wire saw, and we subsequently annealed the specimens in ambient air at $700^{\circ} \mathrm{C}, 800^{\circ} \mathrm{C}, 900^{\circ} \mathrm{C}$, or $1000^{\circ} \mathrm{C}$ for 20 min using an electric furnace (Denken, KDF S-70).

The PL spectra of the $\mathrm{Ta}_{2} \mathrm{O}_{5}: \mathrm{Tm}$, Ce films were measured using a dual-grating monochromator (Roper Scientific, SpectraPro 2150i) and a CCD detector (Roper Scientific, Pixis: $100 \mathrm{~B}$, electrically cooled to $-80^{\circ} \mathrm{C}$ ). A HeCd laser (Kimmon, IK3251R-F, wavelength $\lambda=325 \mathrm{~nm}$ ) was used to excite the films. XRD patterns of the films were recorded using an X-ray diffractometer (RIGAKU, RINT2200VF+/PC system). Tm and Ce concentrations of the films after annealing were measured using an electron probe micro-analyzer (EPMA) (Shimadzu, EPMA1610).

\section{Results and Discussion}

Figure 1 presents PL spectra of specimens prepared from a $\mathrm{Ta}_{2} \mathrm{O}_{5}: \mathrm{Tm}$, Ce film deposited using one Tm $\mathrm{O}_{3}$ pellet and two $\mathrm{CeO}_{2}$ pellets (sample A) and annealed at $700^{\circ} \mathrm{C}, 800^{\circ} \mathrm{C}, 900^{\circ} \mathrm{C}$, or $1000^{\circ} \mathrm{C}$ for $20 \mathrm{~min}$. PL peaks around a wavelength of $800 \mathrm{~nm}$ were observed for specimens annealed at $900^{\circ} \mathrm{C}$ or $1000^{\circ} \mathrm{C}$. The $800-\mathrm{nm}$ peak

Table 1. Three samples prepared in this study.

\begin{tabular}{ccc}
\hline Sample & Number of $\mathrm{Tm}_{2} \mathrm{O}_{3}$ pellets & Number of CeO $\mathrm{O}_{2}$ pellets \\
\hline A & 1 & 2 \\
B & 1 & 1 \\
C & 2 & 1 \\
\hline
\end{tabular}




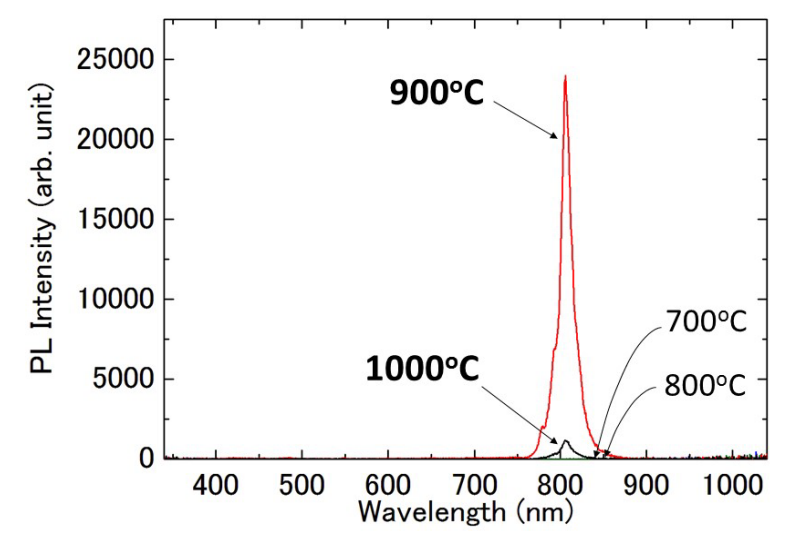

Figure 1. PL spectra of specimens prepared from a $\mathrm{Ta}_{2} \mathrm{O}_{5}$ : Tm, Ce film deposited using one $\mathrm{Tm}_{2} \mathrm{O}_{3}$ pellet and two $\mathrm{CeO}_{2}$ pellets (sample A) and annealed at $700^{\circ} \mathrm{C}, 800^{\circ} \mathrm{C}, 900^{\circ} \mathrm{C}$, or $1000^{\circ} \mathrm{C}$ for $20 \mathrm{~min}$.

seems to be the result of the ${ }^{3} \mathrm{H}_{4} \rightarrow{ }^{3} \mathrm{H}_{6}$ transition of $\mathrm{Tm}^{3+}$ [15]. No PL peak was observed for specimens annealed at $700^{\circ} \mathrm{C}$ or $800^{\circ} \mathrm{C}$. Figure 2 presents PL spectra of specimens prepared from a $\mathrm{Ta}_{2} \mathrm{O}_{5}: \mathrm{Tm}$, Ce film deposited using one $\mathrm{Tm}_{2} \mathrm{O}_{3}$ pellet and one $\mathrm{CeO}_{2}$ pellet (sample B) and annealed at $700^{\circ} \mathrm{C}, 800^{\circ} \mathrm{C}, 900^{\circ} \mathrm{C}$, or $1000^{\circ} \mathrm{C}$ for 20 min. Much stronger PL peaks at almost the same wavelength of $800 \mathrm{~nm}$ were observed for specimens annealed at $900^{\circ} \mathrm{C}$ or $1000^{\circ} \mathrm{C}$ than for those prepared from sample A and annealed at the same temperature. The PL peak intensity of the specimen annealed at $900^{\circ} \mathrm{C}$ was 3.3 times stronger, and that of the specimen annealed at $1000^{\circ} \mathrm{C}$ was 14.4 times stronger than that of the specimen prepared from the sample $\mathrm{A}$ and annealed at the same temperature. Figure 3 presents PL spectra of specimens prepared from a $\mathrm{Ta}_{2} \mathrm{O}_{5}: \mathrm{Tm}$, Ce film deposited using two $\mathrm{Tm}_{2} \mathrm{O}_{3}$ pellets and one $\mathrm{CeO}_{2}$ pellet (sample C) and annealed at $700^{\circ} \mathrm{C}, 800^{\circ} \mathrm{C}, 900^{\circ} \mathrm{C}$, or $1000^{\circ} \mathrm{C}$ for $20 \mathrm{~min}$. PL peaks of specimens annealed at $900^{\circ} \mathrm{C}$ or $1000^{\circ} \mathrm{C}$ were similar to those of samples $\mathrm{A}$ and $\mathrm{B}$, but much weaker than those of sample B.

Figure 4 plots normalized PL peak intensities of the specimens annealed at $900^{\circ} \mathrm{C}$ or $1000^{\circ} \mathrm{C}$ and prepared from samples A, B, and C. In our experiments, sample B exhibited the strongest PL intensity. The Tm concentration of film prepared from sample B and annealed at $900^{\circ} \mathrm{C}$ was measured to be $\sim 1.0 \mathrm{~mol} \%$, and the Ce concentration was measured to be $\sim 1.3 \mathrm{~mol} \%$. These concentrations were thus estimated to be the proper $\mathrm{Tm}$ and $\mathrm{Ce}$ concentrations of such a $\mathrm{Ta}_{2} \mathrm{O}_{5}: \mathrm{Tm}$, Ce film to obtain strong PL intensity.

Figure 5 presents XRD patterns of the specimens prepared from sample $\mathrm{B}$ and annealed at $700^{\circ} \mathrm{C}, 800^{\circ} \mathrm{C}$, $900^{\circ} \mathrm{C}$, or $1000^{\circ} \mathrm{C}$ for $20 \mathrm{~min}$. The specimens annealed at $900^{\circ} \mathrm{C}$ or $1000^{\circ} \mathrm{C}$ had almost the same major diffraction peaks corresponding to the (001); $\delta-\mathrm{Ta}_{2} \mathrm{O}_{5}$ (orthorhombic), (200); $\delta-\mathrm{Ta}_{2} \mathrm{O}_{5}$ (hexagonal); and (201) phases as our rare-earth doped $\mathrm{Ta}_{2} \mathrm{O}_{5}$ sputtered thin films [18]. The three phases seem to be very important for obtaining strong PL peaks from the present $\mathrm{Ta}_{2} \mathrm{O}_{5}: \mathrm{Tm}$, Ce films, in addition to optimizing the $\mathrm{Tm}$ and Ce concentrations.

\section{Summary}

We prepared $\mathrm{Ta}_{2} \mathrm{O}_{5}: \mathrm{Tm}$, Ce thin films using simply co-sputtering of one or two $\mathrm{Tm}_{2} \mathrm{O}_{3}$ and $\mathrm{CeO}_{2}$ pellets on a $\mathrm{Ta}_{2} \mathrm{O}_{5}$ disc for the first time, and $\mathrm{PL}$ properties of the films annealed at $700^{\circ} \mathrm{C}, 800^{\circ} \mathrm{C}, 900^{\circ} \mathrm{C}$, or $1000^{\circ} \mathrm{C}$ for 20 min were evaluated. PL peaks around a wavelength of $800 \mathrm{~nm}$ due to $\mathrm{Tm}^{3+}$ were observed for films annealed at $900^{\circ} \mathrm{C}$ or $1000^{\circ} \mathrm{C}$. The peak intensities of films prepared using one $\mathrm{Tm}_{2} \mathrm{O}_{3}$ pellet and one $\mathrm{CeO}_{2}$ pellet were much stronger than those of films prepared using one $\mathrm{Tm}_{2} \mathrm{O}_{3}$ pellet and two $\mathrm{CeO}_{2}$ pellets, or films prepared using two $\mathrm{Tm}_{2} \mathrm{O}_{3}$ pellets and one $\mathrm{CeO}_{2}$ pellet. The proper Tm concentration to obtain strong PL intensity was estimated to be $\sim 1.0 \mathrm{~mol} \%$, and proper Ce concentration was estimated to be $\sim 1.3 \mathrm{~mol} \%$. Based on XRD measurements, the (001); $\delta-\mathrm{Ta}_{2} \mathrm{O}_{5}$ (orthorhombic), (200); $\delta-\mathrm{Ta}_{2} \mathrm{O}_{5}$ (hexagonal); and (201) phases of the $\mathrm{Ta}_{2} \mathrm{O}_{5}: \mathrm{Tm}$, Ce films seem to be very important for obtaining a strong PL peak. Such light-emitting $\mathrm{Ta}_{2} \mathrm{O}_{5}$-based sputtered films can be used as high-refractive-index materials of autocloned photonic crystals that can be applied to novel light-emission devices, and they will also be used as anti-reflection and down-conversion layers for realizing high-efficiency silicon solar cells. 


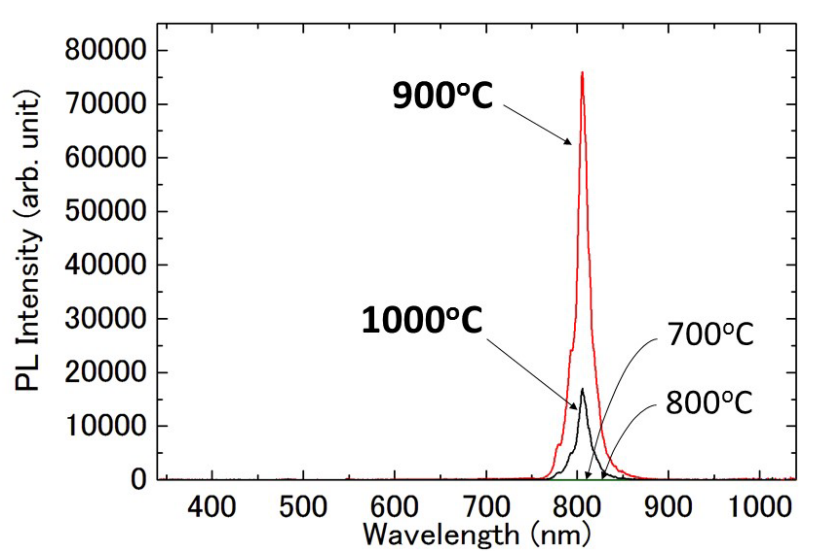

Figure 2. PL spectra of specimens prepared from a $\mathrm{Ta}_{2} \mathrm{O}_{5}: \mathrm{Tm}$, Ce film deposited using one $\mathrm{Tm}_{2} \mathrm{O}_{3}$ pellet and one $\mathrm{CeO}_{2}$ pellet (sample B) and annealed at $700^{\circ} \mathrm{C}, 800^{\circ} \mathrm{C}, 900^{\circ} \mathrm{C}$, or $1000^{\circ} \mathrm{C}$ for $20 \mathrm{~min}$.

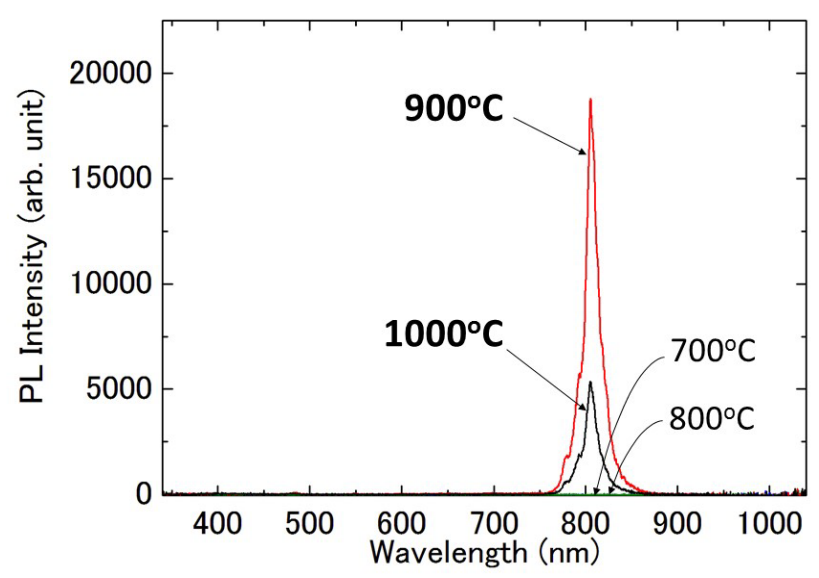

Figure 3. PL spectra of specimens prepared from a $\mathrm{Ta}_{2} \mathrm{O}_{5}: \mathrm{Tm}$, Ce film deposited using two $\mathrm{Tm}_{2} \mathrm{O}_{3}$ pellets and one $\mathrm{CeO}_{2}$ pellet (sample C) and annealed at $700^{\circ} \mathrm{C}, 800^{\circ} \mathrm{C}, 900^{\circ} \mathrm{C}$, or $1000^{\circ} \mathrm{C}$ for $20 \mathrm{~min}$.

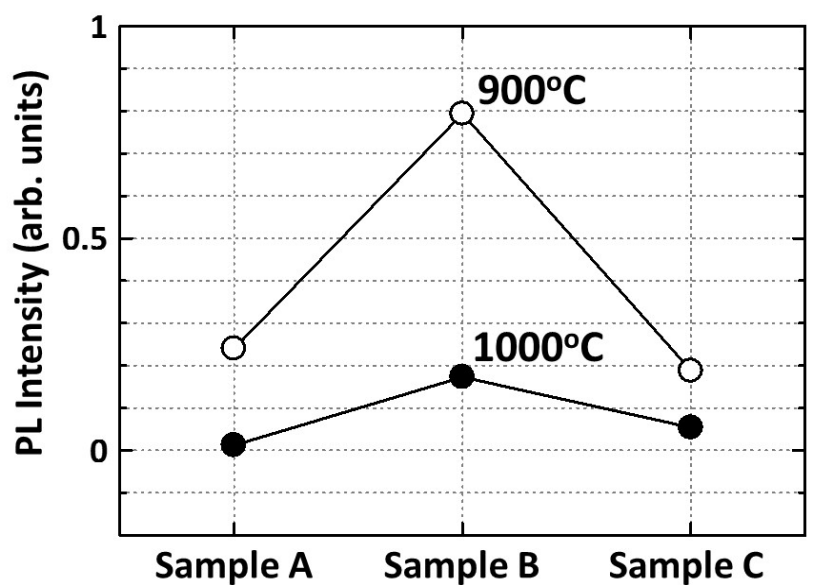

Figure 4. Normalized PL-peak intensities of the specimens annealed at $900^{\circ} \mathrm{C}$ or $1000^{\circ} \mathrm{C}$ and prepared from samples A, B, and C. 


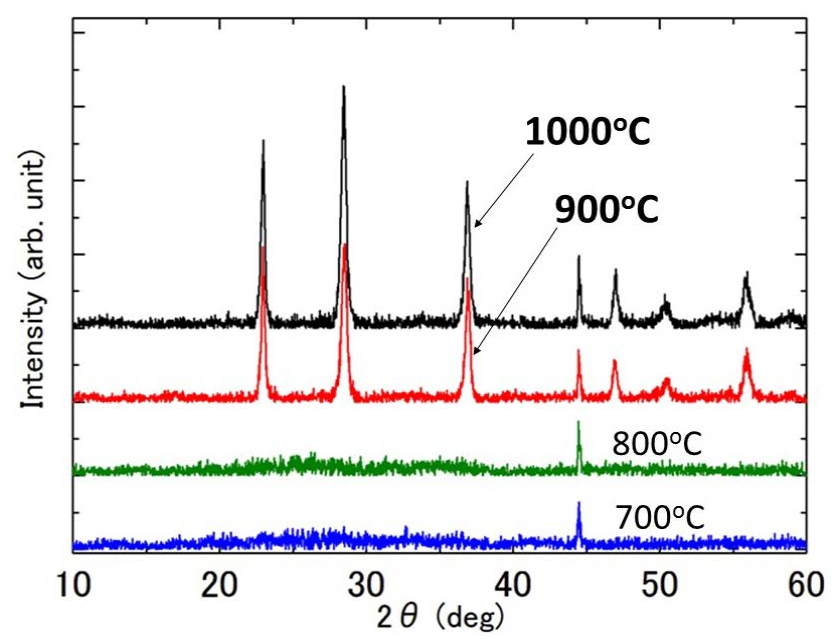

Figure 5. XRD patterns of the specimens prepared from the $\mathrm{Ta}_{2} \mathrm{O}_{5}: \mathrm{Tm}$, Ce film deposited using one $\mathrm{Tm}_{2} \mathrm{O}_{3}$ and one $\mathrm{CeO}_{2}$ pellets (sample B) and annealed at $700^{\circ} \mathrm{C}, 800^{\circ} \mathrm{C}, 900^{\circ} \mathrm{C}$, or $1000^{\circ} \mathrm{C}$ for $20 \mathrm{~min}$.

\section{Acknowledgements}

Part of this work was supported by the "Element Innovation” Project by Ministry of Education, Culture, Sports, Science and Technology in Japan; and JSPS KAKENHI Grant Number 26390073. Part of this work was conducted at the Human Resources Cultivation Center (HRCC), Gunma University, Japan.

\section{References}

[1] Hanaizumi, O., Miura, K., Saito, M., Sato, T., Kawakami, S., Kuramochi, E. and Oku, S. (2000) Frontiers Related with Automatic Shaping of Photonic Crystals. IEICE Transactions on Electronics, E83-C, 912-919.

[2] Sato, T., Miura, K., Ishino, N., Ohtera, Y., Tamamura, T. and Kawakami, S. (2002) Photonic Crystals for the Visible Range Fabricated by Autocloning Technique and Their Application. Optical and Quantum Electronics, 34, 63-70. http://dx.doi.org/10.1023/A:1013382711983

[3] Miura, K., Ohtera, Y., Ohkubo, H., Akutsu, N. and Kawakami, S. (2003) Reduction of Propagation and Bending Losses of Hetero-Structured Photonic Crystal Waveguides by Use of a High- $\Delta$ Structure. Optics Letters, 28, 734-736. http://dx.doi.org/10.1364/OL.28.000734

[4] Zhu, M., Zhang, Z. and Miao, W. (2006) Intense Photoluminescence from Amorphous Tantalum Oxide Films. Applied Physics Letters, 89, Article ID: 021915. http://dx.doi.org/10.1063/1.2219991

[5] Miura, K., Miyazaki, H. and Hanaizumi, O. (2008) Observation of Blue-Light Emission from Tantalum Oxide Films Deposited by Radio-Frequency Magnetron Sputtering. IEICE Transactions on Electronics, E91-C, 1669-1672. http://dx.doi.org/10.1093/ietele/e91-c.10.1669

[6] Sanada, T., Wakai, Y., Nakashita, H., Matsumoto, T., Yogi, C., Ikeda, S., Wada, N. and Kojima, K. (2010) Preparation of $\mathrm{Eu}^{3+}$-Doped $\mathrm{Ta}_{2} \mathrm{O}_{5}$ Phosphor Particles by Sol-Gel Method. Optical Materials, 33, 164-169. http://dx.doi.org/10.1016/j.optmat.2010.08.018

[7] Singh, M.K., Fusegi, G., Kano, K., Bange, J.P., Miura, K. and Hanaizumi, O. (2009) Intense Photoluminescence from Erbium-Doped Tantalum Oxide Thin Films Deposited by Sputtering. IEICE Electronics Express, 6, 1676-1682. http://dx.doi.org/10.1587/elex.6.1676

[8] Singh, M.K., Miura, K., Fusegi, G., Kano, K. and Hanaizumi, O. (2013) Visible-Light Emission Properties of ErbiumDoped Tantalum-Oxide Films Produced by Co-Sputtering. Key Engineering Materials, 534, 154-157. http://dx.doi.org/10.4028/www.scientific.net/KEM.534.154

[9] Miura, K., Arai, Y., Osawa, T. and Hanaizumi, O. (2012) Light-Emission Properties of Europium-Doped TantalumOxide Thin Films Deposited by Radio-Frequency Magnetron Sputtering. Journal of Light \& Visual Environment, 36, 64-67. http://dx.doi.org/10.2150/jlve.36.64

[10] Miura, K., Osawa, T., Yokota, Y. and Hanaizumi, O. (2014) Fabrication and Evaluation of $\mathrm{Ta}_{2} \mathrm{O}_{5}: \mathrm{Y}_{2} \mathrm{O}_{3}$ Co-Sputtered Thin Films. Results in Physics, 4, 185-186. http://dx.doi.org/10.1016/j.rinp.2014.09.004 
[11] Miura, K., Osawa, T., Suzuki, T., Yokota, Y. and Hanaizumi, O. (2015) Yellow Light Emission from Ta $2 \mathrm{O}_{5}: \mathrm{Er}, \mathrm{Eu}, \mathrm{Ce}$ Thin Films Deposited Using a Simple Co-Sputtering Method. Results in Physics, 5, 26-27. http://dx.doi.org/10.1016/j.rinp.2014.11.003

[12] Cid, M., Stem, N., Brunetti, C., Beloto, A.F. and Ramos, C.A.S. (1998) Improvements in Anti-Reflection Coatings for High-Efficiency Silicon Solar Cells. Surface and Coatings Technology, 106, 117-120. http://dx.doi.org/10.1016/S0257-8972(98)00499-X

[13] Rodriguez, V.D., Tikhomirov, V.K., Mendez-Ramos, J., Yanes, A.C. and Moshchalkov, V.V. (2010) Towards Broad Range and Highly Efficient Down-Conversion of Solar Spectrum by $\mathrm{Er}^{3+}-\mathrm{Yb}^{3+}$ Co-Doped Nano-Structured Glass-Ceramics. Solar Energy Materials and Solar Cells, 94, 1612-1617. http://dx.doi.org/10.1016/j.solmat.2010.04.081

[14] Ueda, J. and Tanabe, S. (2011) Broadband Near Ultra Violet Sensitization of $1 \mu \mathrm{m}$ Luminescence in $\mathrm{Yb}^{3+}$-Doped $\mathrm{CeO}_{2}$ Crystal. Journal of Applied Physics, 110, Article ID: 073104. http://dx.doi.org/10.1063/1.3642984

[15] Miura, K., Osawa, T., Yokota, Y., Suzuki, T. and Hanaizumi, O. (2014) Fabrication of Tm-Doped Ta $\mathrm{O}_{5} \mathrm{Thin}$ Films Using a Co-Sputtering Method. Results in Physics, 4, 148-149. http://dx.doi.org/10.1016/j.rinp.2014.08.011

[16] Du, Q., Zhou, G., Zhou, J., Zhou, H. and Zhan, J. (2012) Enhanced Photoluminescence of $\mathrm{CaZrO}_{3}: \mathrm{Er}^{3+}$ by $\mathrm{Efficient}^{3}$ Energy Transfer from $\mathrm{Ce}^{3+}$. Materials Research Bulletin, 47, 3774-3779. http://dx.doi.org/10.1016/j.materresbull.2012.06.022

[17] Roh, J., Hwang, S.H. and Jang, J. (2014) Dual-Functional $\mathrm{CeO}_{2}$ : $\mathrm{Eu}^{3+}$ Nanocrystals for Performance-Enhanced Dye-Sensitized Solar Cells. ACS Applied Materials Interfaces, 6, 19825-19832. http://dx.doi.org/10.1021/am505194k

[18] Bange, J.P., Singh, M.K., Kano, K., Miura, K. and Hanaizumi, O. (2011) Structural Analysis of RF Sputtered Er Doped $\mathrm{Ta}_{2} \mathrm{O}_{5}$ Films. Key Engineering Materials, 459, 32-37. http://dx.doi.org/10.4028/www.scientific.net/KEM.459.32 